\title{
Öğretim Materyali'ne İlişkin Motivasyon Ölçeği (ÖMMÖ) Türkçe Uyarlama Çalışması
}

\section{Turkish Adaptation Study of Instructional Materials Motivation Survey (IMMS)}

\begin{abstract}
Serkan Dinçer, Çukurova Üniversitesi, Eğitim Fakültesi, dincerserkan@cu.edu.tr Ahmet Doğanay, Cukurova Üniversitesi,Eğitim Fakültesi, adoganay@cu.edu.tr
\end{abstract}

\begin{abstract}
öZ. Eğitim bilimlerinde genel olarak akademik başarıya odaklanılmasına rağmen akademik başarıyı etkileyen değişkenlere de odaklanılması gerekmektedir. Bu değişkenlerin başında motivasyon gelmektedir. Motivasyon birçok şekilde ölçülebildiği gibi birçok motivasyon kaynağı da bulunmaktadır. Öğretimin temel öğelerinden biri olan materyallerin bu bağlamda değerlendirilmesi oldukça önemlidir. Bu nedenle çalıșmanın amacı öğretim materyaline ilişkin motivasyonu ölçmeyi sağlayan bir ölçme aracını geliştirmektir. Keller tarafından ARCS Modeli referans alınarak geliştirilen 36 maddeden ve dört faktörden oluşan ölçek (IMMS) bu amaç için seçilerek Türkçeye uyarlaması yapılmıştır. Ölçme aracı örnekleminin ve bazı ifadelerin değişmesi nedeniyle ölçek geliştirme aşamalarının hepsi yeniden tekrarlanmıștır. Ölçme aracının birinci sürüm, ikinci sürüm çalışmaları açıklayıcı faktör analizi ile analiz edilmiş, daha sonra elde edilen ölçek doğrulayıcı faktör analizi ile test edilmiştir. Çalışmaya 1361 ortaokul öğrencisi katılmış, bunların 469'una ait veriler birinci sürüm için, 568'ine ait veriler açıklayıcı faktör analizi için, 295 'ine ait veriler doğrulayıcı faktör analizi için kullanılmıştır. Ölçeğin orijinalinde bulunan olumsuz ifadeler, örneklemin bu ifadeleri kodlayamaması nedeniyle olumlu ifadeye çevrilmiș, üç maddenin olumlu ifadesinin anlamlı olmaması nedeniyle ölçekten çıkartılarak 33 maddelik dört faktörlü bir ölçme aracı elde edilmiştir. Açıklayıcı faktör analizi için iç güvenilirlik katsayısı .93 olarak hesaplanan bu ölçme aracında, doğrulayıcı faktör analizi bulgularının sınır-kabul değerlerinin içinde kaldığı belirlenmiştir. Sonuç olarak elde edilen değerlerden bu ölçme aracının ortaokul öğrencilerinin öğretim materyaline ilişkin motivasyon düzeylerinin belirlenmesinde kullanılabileceği sonucuna ulaşılmıştır.
\end{abstract}

Anahtar Kelimeler. Motivasyon Ölçeği, Öğretim Materyali, ARCS Modeli

\begin{abstract}
Although many studies focus on academic achievement in educational sciences, variables which affect academic achievement should also be examined. Motivation is the prominent variable that enhances academic achievement. Motivation can be measured in various ways and has different sources as well. It is important to evaluate materials, which are one of the essential elements of teaching, in this respect. Thus, the aim of this study is to develop an instrument to assess motivation regarding teaching materials. For this purpose, a 36-item scale consisting of four constructs developed by Keller based on ARCS Motivation Model has been adapted into Turkish. Since some statements and sample of the assessment instrument have been changed, all development steps of the scale were re-enacted from the beginning. Initially, first and second edition of the assessment instrument have been analyzed with explanatory factor analysis; then, the scale obtained has been tested with confirmatory factor analysis. A sample of 1361 middle school students has participated in the study. Out of this sample, the data obtained from 469 have been used for the first edition; the data of 568 participants have been used for explanatory analysis whereas the data obtained from 295 participants have been used for confirmatory factor analysis. Negative statements in the original version of the scale have been transformed into positive ones in order to help the participants, who could not code these negative statements. Three positive statements, which have been found as vague in terms of meaning, have been excluded from the scale to obtain a 33-item assessment instrument with four subscales. For this instrument, the internal reliability coefficient has been found .93 in the factor analysis. As for the values of confirmatory factor analysis, they were found at an acceptable limit value. In conclusion, the results of the study have put forward that this assessment instrument could be used in order to determine middle school students' motivation levels regarding teaching materials.
\end{abstract}

Keywords. Motivation Scale, Teaching Materials, ARCS Motivation Model

\section{SUMMARY}

Purpose and Significance: The aim in using ARCS Model is to implicitly increase academic achievement by enhancing motivation Studies conducted with this purpose in mind revealed positive effects of ARCS Model on academic achievement (Balaban-Sal, 2002; Carey, Carey \& Pearson, 1991; 
Çetin \& Mahiroğlu, 2008; Keller \& Suzuki, 1988, Main, 1993; Means, Jonassen\& Dwyer, 1997; Small, 1997; Song, 1998; Song \& Keller, 1999). There are several scales available to measure motivation in related literature (Aydın, Yerdelen, Gürbüzoğlu-Yalmancı, \&Göksu, 2014; Dede \&Yaman, 2008; Eryllmaz, 2013; Keller, 2008; 2010, Tuan, Chin \& Shieh, 2005). Whereas some of these scales measure motivation on subject, others aim to measure motivation by dealing with teaching materials and factors relating to interest in courses (Keller, 1987; 2006; 2008; 2010). Scales taking ARCS Model as reference are designed by Keller $(1987 ; 2006 ; 2010)$ and have been adapted into various languages. A Turkish adaptation of a version of the scale has been carried out by Kutlu and Sözbilir (2011). After eliminating some items culturally and linguistically inapplicable, the final version of the adapted scale with 24 items is obtained with a Cronbach's Alpha Value of .83. Another adaptation into Turkish by Acar (2009) had a Cronbach's Alpha Value of .92 and no item has been excluded from the scale. Despite the availability of works about motivation scale relating teaching materials, wide range studies are neglected in national literature, which leads us to think that it would be useful to develop a new motivation scale or adapt an effective one. Although there are two versions of Keller's scale adapted into Turkish, we think it would be profitable to make a new adaptation of the scale due to different results reached in these studies and to sample change. The main purpose of this study was to develop a scale that can measure motivation concerning materials used in primary and secondary schools. Developing an assessment instrument related to teaching materials has been set as an aim in this study. In line with this purpose, this assessment instrument developed by Keller (2010) to measure motivation related to teaching materials was adapted into Turkish by with the permission of its author.

Methodology: Validity and reliability analyses of the scale were performed as follows: reliability was evaluated with Cronbach's Alpha analysis; content validity with expert opinions; construct validity with explanatory factor analysis and criterion validity with consistency analysis. Moreover, arithmetic means of the items with their standard deviations and items-total score correlations were examined and item discrimination index values were calculated with t-test.

Results: A Turkish translation of the first version scale was administered to 469 students in two practice schools-where no scale has been applied. Results obtained were first examined with explanatory factor analysis, then with confirmatory factor analysis. But data were determined to be quite non-normally distributed. Reversed items containing negative statements were found as cause of problem items. As excluding reversed items could disrupt the structure of the scale and applying the scale as such could lead to obtain incorrect data, we decided to transform negative items into positive ones. Positively phrased three items were decided to be excluded from the scale because they had no meaningful statements. Second version of the 33-items scale was administered to 590 students in two practice schools-where no scale has been applied. In original version of the teaching material-related motivation scale (IMMS), subscales number was given as four. Confirmatory factor analysis was decided to be performed again due to transforming of the negative items into positive ones, excluding of three items from the scale and thus sample changing in the study. Hence, data from 590 students were coded and prerequisites for explanatory factor analysis were met. After excluding from analysis participants having non-normally distributed extreme or missing values, only data from 568 students were included in analysis. Finally, a 33-item scale with four subscales has been obtained. Reliability coefficients of the scale for subscales were respectively found as .83, .74, .79, .82 and total reliability coefficient was .93. Assessment instrument obtained with explanatory factor analysis was administered to 302 students in a third school for confirmatory factor analysis. Data from these students were coded and prerequisites for confirmatory factor analysis were also met. Participants having non-normally distributed extreme or missing values were excluded from analysis, only data from 295 students were included in analysis. Necessary conditions were then tested before the scale has been decided to be applicable.

Discussion and Conclusions: For reliability of the scale, internal coefficients of consistency were examined; Cronbach's alpha internal consistency was calculated as .93 with explanatory factor analysis and .97 with confirmatory factor analysis. These two different internal coefficients of consistency were concluded to be compatible with those obtained while works on developing of the 
original scale and those in other studies which made use of it. Additionally, explained total variance of the 33-items assessment instrument with four subscales was calculated as $47.50 \%$. Some researchers (Sheskin, 2004) indicate that explained total variance should be at least $70.00 \%$ while other researchers (Tavşancll, 2002) state that it should be minimum $40.00 \%$. Some others (Büyüköztürk, 2005) point out that explained total variance can be acceptable with a value $30.00 \%$ and above. In terms of fit indices, the scale had values as follows: $\chi^{2} / \mathrm{sd}=2.32$, SRMR $=.04, \mathrm{RMSEA}=$ .07 , AGFI=.78, GFI=.81, NFI=.97, and CFI=.98. For Byrne (1998), these values point allowable fits. Based on this consideration, construct (structure) of the scale was revealed to have allowable fits. Although out of the scope of the study, it is remarkable to determine middle school students failed to perceive and could not correctly code reversed items. Reversed items in assessment instrument to be used are not suggested for participants in this age group. In addition to this suggestion, it is also recommended to reapply the assessment instrument in larger sample groups, to reconsider confirmatory factor analysis and to make an overall assessment by compiling and linking the results of this study with other IMMS studies conducted in national literature.

\section{Gİiş}

Motivasyon TDK (2015)'ya göre isteklendirme ve güdüleme anlamındadır. Ancak daha geniş tanımlamaları da ilgili alan yazında bulunmaktadır. Örneğin ilk motivasyon tanımı Woodworth (1918) tarafından "bir organizmayı çeşitli şekillerde harekete geçiren enerji birikimi" șeklinde ifade edilmiştir. Buna ek olarak, Lussier (1990) motivasyonu "bireyin ihtiyaçlarını karşılamak üzere, ihtiyaç duyulan davranışa yönlendiren içsel süreç" olarak tanımlarken, Keller (1983) "davranışın yönü ve büyüklüğü; çabanın göstergesi" olarak tanımlamıștır. Bunlara ek olarak Brophy (1998) motivasyonu "amaç yönelimli davranışın başlama yönünü, kararlılığını açılklamada kullanılan kavram” şeklinde, Watters ve Ginns (2000) “davranışın ortaya çıkması için harcanan çabayı gösteren psikolojik yapı" olarak tanımlamıştır.

Motivasyon, başta psikoloji olmak üzere tüm alanlarda sıklıkla incelenen konulardan birisidir (Eryılmaz ve Ercan, 2014). Motivasyon için birçok gruplama yapılmış olsa da motivasyon genel olarak içsel ve dışsal motivasyon olarak iki gruba ayrılmıştır (Ersarı ve Naktiyok, 2012; Eryılmaz ve Ercan, 2014; Mottaz,1985; Steers ve Porter, 1991). Bu motivasyon türleri psikoloji ve eğitim bilimleri alanlarında Öz Belirleyicilik Kuramı kapsamında incelenmektedir. Öz Belirleyicilik Kuramı içseldışsal motivasyonun var olduğunu ve motivasyonun olmamasını içermektedir (Deci ve Ryan, 2000). Reeve (2004), bireyin kendi eylemleri ile eylemlerinin sonuçları arasındaki bağlantıyı algılayamadığında, motivasyonun oluşmayacağı ifade etmektedir.

İçsel motivasyon, kişinin davranışını düzenleyen dişsal bir kontrol olmaksızın, kişinin kendisi tarafından motive edilmesi (Mottaz, 1985) olarak tanımlandığı gibi, eğitim bilimlerinde bireyin öğrenmeye duyduğu merak, başarmanın verdiği haz şeklinde ifade edilmektedir (Deci ve Ryan 1985; Harter 1981; Lepper 1988). İçsel motivasyon ilgi çekici, işe katılım, sorumluluk, yaratıcılık, performans gibi faktörleri içermektedir. Özetle içsel motivasyon, bireyin içinde var olan ihtiyaçlarına yönelik tepkilerdir (Ersarı ve Naktiyok, 2012). Dışsal motivasyon ise bireyin çevresinden gelen etkileri göstermektedir. Bireyin diğer bireylerden takdir alması, ödül kazanması gibi dış kaynaklı etmenlerden dolayı gösterdiği çabayı ifade etmektedir (Deci, 1972; Deci ve Ryan 1985; Newstrom ve Davis, 2002). Dişsal etkenler motivasyonu arttırmada oldukça önemlidir; ancak, içsel motivasyonu yaratan etkenler olmadan dışsal etkenler çoğu zaman gerekli motivasyonu sağlayamamaktadır (Ersarı ve Naktiyok, 2012).

Motivasyonun eğitim bilimlerinde kullanılmasının temel nedenlerinden birisi akademik başarı ile ilişskisidir. Yapılan araştırmalar öğrencilerin motive olduklarında davranışlarını o konuyu başarmak adına düzenlediğini; öğrenme ortamlarında daha uygun davranışlar sergilediklerini ve akademik başarı açısından daha iyi sonuç elde ettiklerini göstermektedir (Ahmed ve Bruinsma, 2006; Eccles, Wigfield ve Schiefele, 1998; Keller, 1987; 1999; 2010; Kutlu ve Sözbilir, 2011; Slavin, 2003; Pintrich ve Maehr, 2004). Araştırmalar içsel motivasyon, öğrenme stratejileri ve başarı arasında olumlu ilişskililerinin olduğu sonucuna ulaşmıștır (Chan, Wong, veLo, 2012; Fortier, Vallerand, ve Guay; 1995; Gillet, Vallerand, ve Lafreniere, 2012; Niemiec ve Ryan, 2009; Pajares, 1996; RyanveDeci, 2000; SchunkvePajares, 2001; WoltersveRosenthal, 2000). Materyallerin tasarlanması sürecinde içsel motivasyonun dikkate alınması bu nedenle oldukça önemlidir (Dalgety, CollveJones, 2003; 
Glynn, Taasoobshirazi ve Brickman, 2007; Zusho, Pintrich ve Coppola, 2003). Özellikle bilgisayar destekli öğretim yazılımlarında dikkati çekme faktörünün önem kazanması, bu nedenlerden birisidir.

Motivasyon ile ilgili teorilerden biri, Maslow'un Motivasyon Teorisi'dir. Maslow, bireyin ihtiyaçlarının sınırsız olduğu savunmaktadır. Bu teoriye göre motivasyonun kaynağı, bireyin tatmin edilmemiş ihtiyaçlarıdır. Bu ihtiyaçlar bireyi güdülemekte, bu güdülemede bireyi davranışa yöneltmektedir (Aladağ, 2007). Maslow bireyin bu ihtiyaçlarını fizyolojik, güvenlik, sevgi, saygısı ve kendini gerçekleştirme olarak gruplamıştır (Maslow, 1943). Bu ihtiyaçlar ve güdülemeler uygun araçlar ile kullanıldığında birey, sürekli olarak motive olabilmektedir (Kaplan, 2007). Malone ve Lepper (1987) tarafından önerilen diğer bir motivasyon kuramının temelini "dışsal motivasyonun içsel motivasyondan daha yararlıdır" ifadesi oluşturmaktadır. Araştırmacılar içsel motivasyonu meydan okuma, fantezi, merak ve kontrol adlı dört bileşen ile açılamaktadır. Bu motivasyon kuramında öğrenmeyi eğlenceli hale getirmek amacıyla öğrenme ortamları, içsel motivasyonu artıracak şekilde tasarlanmıştır. Araştırmacılar, öğrenme ortamında sadece eğitsel aktivitelerin yeterli olmadığını, buna ek olarak öğrencilerin bu aktiviteleri yerine getirecek içsel motivasyonlara ihtiyaç duyduklarını; buna paralel olarak içsel motivasyonla öğretim etkinliği arasında önemli bir ilişkinin var olduğunu belirtmişlerdir.

İlgili alan yazında yukarıdaki kuramlara ek olarak birçok model bulunmaktadır. Ancak öğretim tasarımları ve motivasyon ilișkisini ele alan modellerin bașında Keller'in (1987) ARCS Modeli gelmektedir. ARCS Modeli ismini temel boyutları olan dikkat (attention), uygunluk (relevence), güven (confidence), memnuniyet (satisfaction) kelimelerinin İngilizce karşıllklarının baş harflerinden almaktadır. Keller 1979 yılında bu modelin ilk boyutlarını yayınlamış, 1987 yılında ARCS Modeli'ni olușturmuştur. Son olarak 2008 yılında, bu modele istem ve öz düzenleme (volitionand self-regulation) ilkelerini ekleyerek beşinci boyutu oluşturmuştur (Cobb, 2013; Keller, 2008).

Keller (2008) dikkat boyutunda, materyallerin öğrenenin dikkatini çektiği zaman öğrenen motivasyonunun artırdığını belirtmiştir. Öğrenenlerin dikkatini çekebilmek için algısal uyarılma, sorgulama uyarılması ve değişebilirlik içeren stratejilerin belirlenmesi gerekmektedir (Keller, 2010). Algısal uyarılma, ortamların değiștirilmesi ile aktif hale gelebilmektedir (Cobb, 2013). Sorgulama uyarılması, öğrenenin merakını tatmin edebilmek için problem çözmeleri ve soru sormalarının teşvik edilmesini içermektedir. Son olarak değişebilirlik, dikkati çektikten sonra dikkati sürdürebilmek için kullanılmaktadır. Bu durum çeşitli öğretim ögeleri ile mümkün olabilmektedir (Dede, 2003). Keller (2010) öğrenenlerin uyarıcılara alışmadan önce ilgilerini kaybettiğini belirtmiştir. Bu nedenle öğrencilerin dikkatini sürekli çekebilmek için çeşitli ses tonları, ilginç grafik ve resimler kullanılmasının yararlı olacağını önermiştir.

ARCS Modeli'nin ikinci boyutu olan uygunluk, öğrenenlerin beklenti ve ihtiyaçlarını tespit edip, öğrenme çıktılarının önemi hakkında öğrenenleri bilgilendirmeyi içermektedir. Öğrenen öğrenme çıktılarının önemini öğrendiği zaman, hayatta bunları neden kullanması gerektiğini bilecek ve motive olabilecektir (Keller, 2010;Lauve Woods, 2009). Bu boyutun üç alt odağı bulunmaktadır. Bunlar; sunulan bilgilerin somutlaştırılarak öğrenen birikimleri ile ilişkilendirilmesini içeren yakınlık (familiarity), öğretim hedefinin belirtilmesini içeren hedefe yöneltme (goal orientation) ve öğrenene uygun stratejileri içeren güdü uygunluğudur (motive matching).

Üçüncü boyut olan güven, öğrenenlerin olumlu tavır geliştirerek başarılarının artmasına yardımcı olmaktadır. Keller (2010) öğrenenlerin başarıyı elde edilmeleri için verilen görev açısından kendilerini becerikli hissetmelerinin gerekli olduğunu belirtmiştir. Bu nedenle öğretim tasarımının güvene dayalı tasarlanması, motivasyonun dolayısı ile akademik ders başarısının artmasını sağlayacaktır. Uygunluk boyutunda olduğu gibi bu boyutunda alt boyutları bulunmaktadır. Bunlar başarı elde edebileceklerinin kazandırılmasını içeren başarı beklentisi (expectancy for success); başarı elde edebilmeleri için uygun firsat, ortam ve olanakların sağlanmasını içeren sınama uyarlaması (challenge setting) ve gösterilen çabayı vurgulayan ve öğreneni destekleyici dönütlerin verilmesini içeren dönüt kalıplarıdır (attribution molding).

Memnuniyet boyutu, çlktılar ile öğrenen beklentileri arasındaki ilişkiyi göstermektedir. Öğrenen umduğu beklentiyi çıtılarda göremediği zaman motivasyon kaybına uğrayabilmektedir (Keller, 2008). Bu nedenle tasarımcılar motivasyonu artırmak ve sürdürebilmek için dışsal pekiştireçleri uygun, beklentilerden yüksek tutmayacak şekilde, gerektiği ölçüde vermelidir; bu 
sayede içsel motivasyon olması gerektiği boyutta kalarak memnuniyet faktörü sağlanabilecektir (Keller, 2008; 2010; Keller veKopp, 1987; Main, 1993).

Keller'in (2008) son eklediği boyut olan istem ve öz düzenleme, öğrenenlerin kendi stratejilerini düzenleyerek motivasyonlarını arttırmasını içermektedir (Cobb, 2013). Böylelikle kalıcılığın sağlanabileceği vurgulanmaktadır.

Gerek ARCS Modeli gerekse de diğer motivasyon modellerinin uygulamasında amaç öğretimin tasarlanması ile doğrudan akademik bașarıyı artırmak değildir (Keller, 2008; Main, 1993; Marovitz ve Buckley; 1987). ARCS Modeli uygulanmasındaki amaç, motivasyonun artırılarak, akademik başarının dolaylı yoldan artırılmasıdır. Bu amaç doğrultusunda yapılan araştırmalar ARCS Modeli'nin akademik başarı üzerinde olumlu etkisi olduğunu göstermiştir (Balaban-Salı, 2002; Carey, Carey ve Pearson, 1991; Çetin ve Mahiroğlu, 2008; Keller ve Suzuki, 1988, Main, 1993; Means, Jonassen ve Dwyer, 1997; Small, 1997; Song, 1998; Song ve Keller, 1999).

İlgili alan yazın incelendiğinde motivasyonun ölçülmesi için birçok ölçek bulunmaktadır (Aydın, Yerdelen, Gürbüzoğlu-Yalmancı, ve Göksu, 2014; Dede ve Yaman, 2008; Eryılmaz, 2013; Keller, 2008; 2010, Tuan, Chin ve Shieh, 2005). Bu ölçeklerin birçoğu belirli bir ders/konu üzerindeki motivasyonu ölçerken, bazıları öğretim materyalini ve derse ilgi unsurlarını ele alarak motivasyonu ölçmeyi amaçlamıștır (Keller, 1987; 2006; 2008; 2010). ARCS Modeli'ni referans alan ölçekler Keller (1987; 2006; 2010) tarafından geliştirilmiş, birçok dilde farklı uyarlamaları yapılmıştır. Türkçe uyarlamasının bir sürümü Kutlu ve Sözbilir (2011) tarafından yapılmıș, ancak bu ölçeğin kültür ve dil açısından bazı maddeleri elenmiştir. Sonuçta Cronbach Alpha İç Tutarlık Katsayısı 83 olan 24 maddelik bir ölçek elde edilmiştir. Diğer bir uyarlama çalışması Acar (2009) tarafından yapılarak Cronbach Alpha İç Tutarlık Katsayısı .92 olarak hesaplanmış ve hiçbir madde ölçekten çıkarılmamıștır.

Öğretim materyaline yönelik motivasyon ölçeği çalışmalarına alanyazında ulaşılmasına rağmen geniş kapsamlı çalışmalara ulusal alanda fazla yer verilmediği dikkati çektiğinden, bir motivasyon ölçeğinin geliştirilmesi ya da uyarlanmasının yararlı olacağı düşünülmüştür. $\mathrm{Bu}$ düşünceden yola çıkarak Keller'e ait bu ölçeğin iki farklı Türkçeye uyarlaması olmasına rağmen iki çalışmada farklı bulgulara ulaşılması ve ölçek evreninin değişmesi nedeniyle ölçeğin tekrardan Türkçeye uyarlanmasının yararlı olacağına karar verilmiștir. Bu nedenle bu çalışmanın ana amacı ilkortaokul düzeyinde kullanılan materyallere ilişkin motivasyonun ölçülmesini sağlayacak bir ölçme aracı uyarlamak olarak belirlenmiştir.

\section{YÖNTEM}

Bu çalışmada öğretim materyaline ilişkin motivasyonun belirlenmesini sağlayacak bir ölçme aracının geliştirilmesi amaçlanmıştır. Bu amaç çerçevesinde, Keller (2010) tarafından geliştirilen öğretim materyaline ilişkin motivasyonu ölçmek amacıyla hazırlanan ölçme aracı, araştırmacının onayı ile Türkçeye uyarlanmıştır. Çalışmada ölçek uyarlama basamakları aşağıda açıklanmıştır.

\section{Çalışma Grubu}

Ölçek uyarlama sürecine açılklayıcı (birinci, ikinci sürüm olmak üzere) ve doğrulayıcı faktör analizi için araştırmaya, üç farklı ortaokulda öğrenimlerini sürdüren toplam 1361 ortaokul öğrencisi katılmıştır. Ölçeğin birinci sürümüne 469 öğrenci katılmış; ancak, ölçeğin -"ölçek uyarlama süreci" başlığında belirtilen nedenlerden dolayı- revize edilmesi sonucunda bu öğrencilere ait veriler kullanılamamıştır.

Uyarlama sürecinin ikinci sürümüne iki farklı ortaokulda öğrenimlerini sürdüren 590 öğrenci katılmıştır; ancak, uç değere ve eksik verilere sahip öğrenci verileri çalışma dışında tutularak Tablo 1'de betimsel istatistikleri verilen 568 öğrenci Öğretim Materyaline İlişkin Motivasyon Ölçeği (ÖMMÖ) açıklayıcı faktör analizine katılmıştır. 
Tablo 1. ÖMMÖ Gelişstirme Süreci, Açıklayıcı Faktör Analizi İçin Kullanılan Ölçekleri Dolduran Öğrencilere Ait Betimsel İstatistikler.

\begin{tabular}{|c|c|c|c|c|c|}
\hline \multirow{2}{*}{ Sinıflar } & \multicolumn{2}{|c|}{ Okul 1} & \multicolumn{2}{|c|}{ Okul 2} & \multirow{2}{*}{ Toplam } \\
\hline & $\mathrm{Klz}$ & Erkek & $\mathrm{Klz}$ & Erkek & \\
\hline 5. Sinıf & - & - & 32 & 33 & 65 \\
\hline 6. Sinif & - & - & 34 & 33 & 67 \\
\hline 7. Sinif & 57 & 60 & 33 & 26 & 176 \\
\hline 8. Sinif & 90 & 78 & 49 & 43 & 260 \\
\hline Toplam & 117 & 138 & 148 & 135 & \\
\hline G.Toplam & & & & & 568 \\
\hline
\end{tabular}

Uyarlama süreci doğrulayıcı faktör analizi için diğer iki ortaokuldan farklı bir ortaokulda öğrenimlerini sürdüren 302 öğrenciye ÖMMÖ uygulanmıştır. Normal dağılım dışında kalan uç ve kayıp verilere sahip ölçekler analiz dışında bırakılarak, Tablo 2'de betimsel istatistikleri verilen 295 katılımcıya ait veriler, doğrulayıcı faktör analizi için kullanılmıștır.

Tablo 2.ÖMMÖ Geliştirme Süreci Doğrulayıcı Faktör Analizine Katılan Öğrencilere Ait Betimsel Istatistikler.

\begin{tabular}{lrrr}
\hline \multirow{2}{*}{ Sinif } & Okul 3 & & \multirow{2}{*}{ Toplam } \\
\cline { 2 - 3 } & Kiz & Erkek & \\
\hline 5. Sinif & 17 & 17 & 34 \\
6. Sinıf & 15 & 20 & 35 \\
7. Sinıf & 51 & 48 & 99 \\
8. Sinıf & 56 & 71 & 127 \\
\hline Toplam & 139 & 156 & 295 \\
\hline
\end{tabular}

\section{Veri Analizi}

Ölçeğe ait geçerlik ve güvenirlik çalışmaları, güvenirlik için Cronbach Alpha analizi, kapsam geçerliği için uzman görüşleri, yapı geçerliği için açıklayıcı faktör analizi, ölçüt geçerliği için tutarlılık analizi tercih edilmiştir. Buna ek olarak, maddelerin aritmetik ortalamaları, standart sapmaları, madde-toplam puan korelasyonları incelenerek, $t$-testi ile madde ayırıcılık güçleri hesaplanmıştır.

\section{Ölçek Uyarlama Süreci}

Keller tarafından 1993 yılında geliştirilen ÖMMÖ, daha sonra güncellenerek taslak sürümü (Keller, 2006) yayımlanmıştır. Taslak sürümünden sonra bir değişiklik yapılmadan Keller (2010) tarafından orijinal sürümü yayınlanmıştır.

Orijinal sürümü 36 maddelik beşli likert tipi (çok doğru, doğru, orta derecede doğru, doğru, biraz doğru, doğru değil) bir ölçek olan ÖMMÖ, ARCS Modeli referans alınarak geliştirilmiştir. Ölçek ARCS Modeli'nin dikkat, uygunluk, güven ve memnuniyet bileşenleri ile aynı adı taşıyan dört alt ölçekten (faktörden) oluşmaktadır. Ölçekteki 3, 7, 12, 15, 19, 22, 26, 29, 31 ve 34. maddeler olumsuz ifade taşımakta ve ters puanlamayı gerektirmektedir. Orta noktası 108.00 olan ölçekten alınabilecek en düşük puan 36.00, en yüksek puan ise 180.00'dir. Orijinal ölçek Keller (2006) tarafından üniversite öğrencilerine uygulanmış, ölçeğin Cronbach Alpha İç Tutarlık Katsayısı .96 olarak hesaplanmıştır. Buna ek olarak ölçeğin faktörleri için yapılan analizler sonucunda faktörlerin Cronbach Alpha iç tutarlık katsayıları sırası ile .89, .81, .90 ve .92 olarak hesaplanmıştır. Ölçeğin orijinal sürümü birçok çalışmada kullanılmış ve güvenilirlik katsayılarının kullanılabilir seviyelerde olduğu belirtilmiştir (Cobb, 2013; Gabrielle, 2003, Huangvd., 2006; Huett, 2006).

ÖMMÖ'nün ulusal alanda kullanımı için Türkçeye uyarlaması, Acar (2009), Kutlu ve Sözbilir (2011) tarafından yapılmıştır. Acar (2009) tarafından Cronbach Alpha İç Tutarlık Katsayısı .92olarak hesaplanan uyarlama çalışmasında, hiçbir madde ölçekten çıkarılmamış ve orijinal ölçekteki gibi dört alt ölçekli (faktörlü) bir yapı elde edilmiştir. Bu faktörlere ait Cronbach Alpha iç tutarlık katsayıları sırası ile $.84, .81, .72$ ve .85 olarak hesaplanmıștır. Kutlu ve Sözbilir (2011) tarafından uyarlaması yapılan ölçekte ise iki alt ölçekli (faktörlü) bir yapı elde edilerek on iki madde ölçek dışında 
tutulmuştur. Faktörler dikkat-uygunluk ve güven-tatmin olarak adlandırılmış, ölçeğin Cronbach Alpha İç Tutarlık Katsayısı .83, faktörlerin Cronbach Alpha iç tutarlık katsayıları sırası ile .79 ve .69 olarak hesaplanmıştır.

Türkçeye uyarlaması olan iki çalışmada farklı bulgulara ulașılması ve ölçeğin orijinal sürümü, üniversite öğrencilerine uygulanmasıyla ölçek evreninin değişmesi nedenlerinden dolayı ölçeğin tekrardan Türkçeye uyarlanmasının yararlı olacağına karar verilmiş, ölçeği geliştiren araştırmacıdan izin alınarak, ölçek uyarlama basamaklarının tamamı, yeniden yapılmıştır.

ÖMMÖ'nin yeniden Türkçeye uyarlama çalışmasında, ilk olarak doktorası İngiliz Dili Eğitimi Anabilim Dalı olan iki uzman tarafından orijinal ölçek, Türkçeye tercüme edilmiştir. İki farklı kişi tarafından tercümesi yapılan ölçek maddeleri araştırmacı tarafından orijinali ile karşılaştırılmış, ortaokul öğrencilerinin daha net anlayabilmeleri için bazı maddelere ait ifadeler değiştirilmiş, açıklamalar eklenmiştir. Ölçeğin son hali üçüncü bir uzmanın görüşüne sunulmuş, orijinal ölçekten farklı olmadığının teyidi istenmiştir. Uzman onayından sonra ölçeğin maddeleri evrenini temsil eden beş ortaokul öğrencisine okutulup ne anladıkları sorulmuştur. Öğrencilerden gelen dönütler doğrultusunda bazı düzeltme ve açıklamalar eklenmiş; bazı kelimelerin yerlerine eş anlamlıları kullanılmıştır. Ölçeğin düzeltilmiş hali tekrar uzman görüşüne sunularak, ifadelerde kayma ya da değişme olmadığının onayı alınmıștır.

Ölçeğin Türkçeye uyarlanmış birinci sürümü, iki uygulama okulunda 469 öğrenciye uygulanmıştır. Elde edilen veriler öncelikle açıklayıcı daha sonra doğrulayıcı faktör analizi ile incelenmiştir. Ancak verilerin normal dağılımdan oldukça sapma gösterdiği tespit edilmiştir. Yapılan inceleme sonunda sorunlu maddelerin, olumsuz ifade barındıran ters maddelerde olduğu anlaşılmıştır. Ters maddelerin ölçek dışında tutulmasının ölçeğin yapısını bozacağı ya da ölçeğin bu hali ile uygulanmasının yanlış bulgular elde edilmesine yol açacağından, ölçekteki olumsuz ifadelerin olumlu ifadelere çevrilmesine karar verilmiştir. Üç maddenin $(12,26,31)$ olumlu ifadesinin anlamlı bir ifadeye karşılık gelmemesinden dolayı, bu maddelerin ölçekten çıkarılmasına karar verilmiştir.

Otuz üç maddelik ölçeğin ikinci sürümü, iki uygulama okulunda -daha önce bu ölçeğin uygulanmadığı- 590 öğrenciye uygulanmıştır. ÖMMÖ'nin orijinal sürümünde faktör (alt ölçek) sayısı dört olarak verilmiştir. Ancak olumsuz ifadelerin olumlu ifadeye dönüştürülmesi, üç maddenin ölçek dışında tutulması ve ölçek evreninin değişmesi nedeniyle açılayıcı faktör analizinin tekrar yapılmasına karar verilmiştir. Bu nedenle 590 öğrenciye ait veriler kodlanmış, açıklayıcı faktör analizi için gerekli ön koşullar test edilmiştir. Normal dağılmayan aşırı uç ya da kayıp değere sahip olan katılımcıların verileri analizden çıkartılmış, Tablo 1'de gösterilen 568 öğrenciye ait veriler, analize dahil edilmiştir.

Açıklayıcı faktör analizi sonucunda elde edilen ölçme aracı, doğrulayıcı faktör analizi için üçüncü bir okulda 302 öğrenciye uygulanmıştır. Bu öğrencilere ait veriler kodlanmış, doğrulayıcı faktör analizi için gerekli ön koşullar test edilmiştir. Normal dağılmayan aşırı uç ya da kayıp değere sahip olan veriler analizden çıkartılmış, Tablo 2'de gösterilen 295 öğrenciye ait veriler, analize dahil edilmiştir. Bu aşamadan sonra gerekli koşullar test edilerek, ölçeğin kullanılabilir olduğuna karar verilmiştir.

\section{BULGULAR}

Araştırmada 568 öğrencinin verileri ile açıklayıcı faktör analizi, 295 öğrencinin verileri ile doğrulayıcı faktör analizi gerçekleştirilmiştir. Ölçeğin güvenilirliğini güçlendirmek için bu iki farklı analiz için verileri kullanılan öğrenciler, farklı okullardan tesadüfi olarak seçilmiştir.

Ölçek uyarlama süreci açıklayıcı faktör analizi için kullanılan 568 veri setinden -normal dağılıma yaklaşan- maddelerin toplam puanı her katılımcı için hesaplanmıştır. Bu hesaplamadan sonra her maddenin puanları ve toplam puanları en düşükten en yükseğe doğru sıralanarak alt \% 27 $(n=153)$ ve üst \% 27'lik ( $n=153)$ gruplar oluşturulmuştur. Daha sonra maddelerin bu iki grubu birbirinden ayırt edip etmediği incelenmiştir. Bu inceleme sonucunda tüm maddelerin ve toplam puanın grupları anlamlı $(\mathrm{p}<.05)$ bir şekilde ayırt edebildiği sonucuna ulaşılmıştır. Buna ek olarak ölçeğe ait 33 maddenin aritmetik ortalamalarının 3.58 - 4.49 aralığında, standart sapmalarının .91 1.62 aralığında olduğu belirlenmiştir. 
Faktör analizinin başında, verilerin faktör çözümlemesine uygun olup olmadı̆̆ının belirlenmesi gerekmektedir. Bu uygunluğu test etmek için Kaiser-Meyer-Olkin (KMO) katsayısı ve BarlettSphericty testi sonuçları incelenmiş, bu değerlerin istatistiksel olarak anlamlı olduğu görülmüştür (KMO = .95; BarlettSphericty testi $\left.\chi^{2}=7312.64, d f=528, p<.01\right)$.

Faktör analizinin ilk sonuçlarından, ölçeğin öz değeri 1.00'in üzerinde olan altı bileşenin olduğunu görülmüştür. Ancak bu altı bileşene dahil olan maddelerin yük değerlerinin birbirine yakın olduğu görülmüştür. Toplam faktör sayısına karar verme sürecinde en sık kullanılan ölçütler öz değer, toplam varyansa katkı yüzdesi ve çizgi grafiğidir (screeplot) (De Vellis, 2003; Doğanay ve Sarı, 2012; Kalaycı, 2009). Çizgi grafiğinin yatay eksene paralel olma noktasının, faktör sayısını belirlemede bir ölçüt olarak kullanılabileceği belirtilmektedir. Ölçek maddelerine ait öz değerlerin çizgi grafiği incelendiğinde, en belirgin kırılmanın Şekil 1'de gösterildiği gibi üç faktörde olduğu gözlenmiştir.

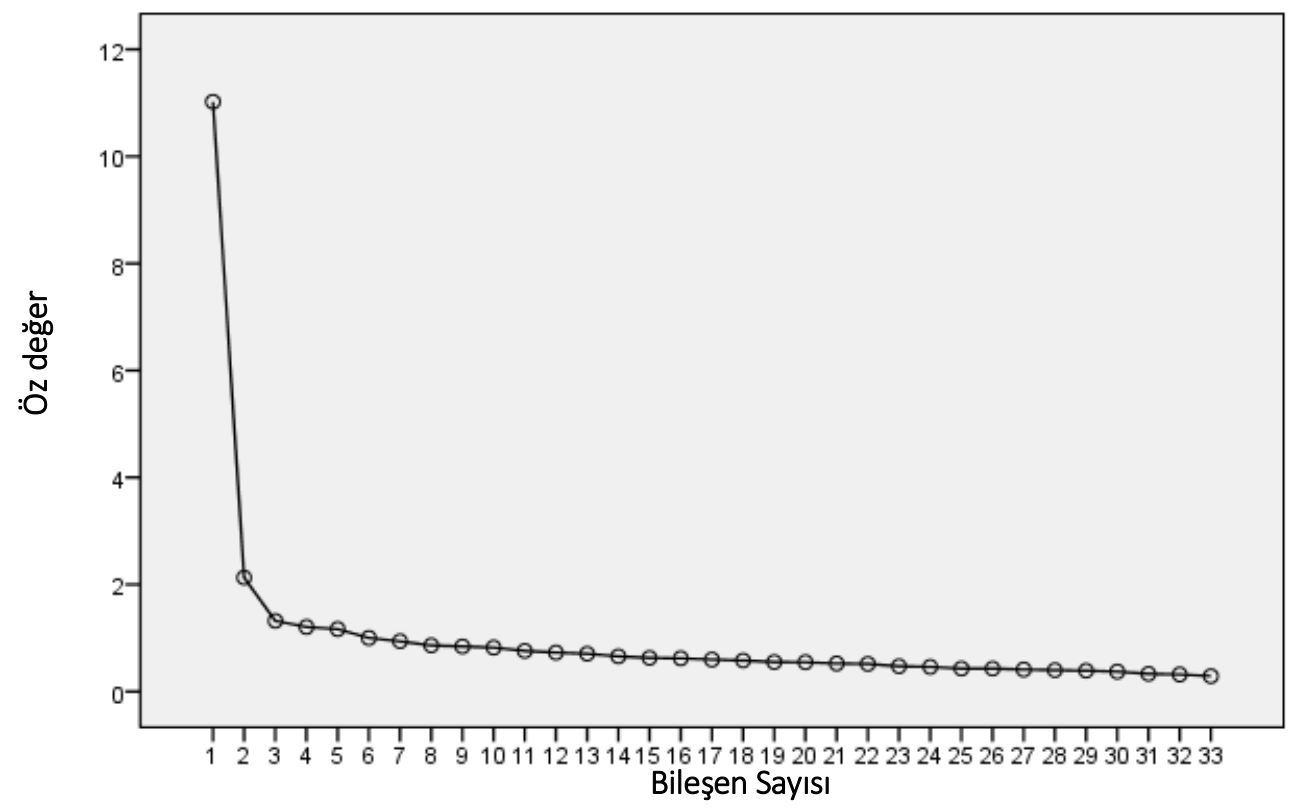

Şekil 1.ÖMDÖ’ye ait çizgi grafiği (screeplot).

Orijinal formunda dört faktör olarak verilen ÖMMÖ, üç faktör olarak ele alınmasının uygun olduğuna karar verilmiş, ancak, üç faktörlü yapıda bazı maddelere ait yüklerin birbirine yakın çıkması nedeniyle tekrar dört faktörlü yapının kullanılmasına karar verilmiştir. Dört faktörlü bir yapıyla ele alınan ölçeğin faktör analizi ile güvenirlik analizlerinden elde edilen değerler Tablo 3'de gösterilmiştir.

Tablo 3'de de görüldüğü üzere ölçekte yer alan otuz üç madde dikkat, uygunluk, güven ve memnuniyet adında dört faktörde toplanmıștır. Dikkat faktöründe yer alan 10 maddenin faktör yükleri .54 - .74, madde-toplam puan korelasyonları ise .48 - .70 aralığındadır. Alt ölçeğe ait Cronbach Alpha İç Tutarlık Katsayısı ise .83'tür. ÖMMÖ'nin ikinci alt ölçeği olan uygunluk faktöründe yer alan sekiz maddenin faktör yükleri $.47-.71$, madde-toplam puan korelasyonları ise .44 - .63 aralığındadır. Alt ölçeğe ait Cronbach Alpha İç Tutarlık Katsayısı ise .74'dür. ÖMMÖ'nin üçüncü alt ölçeği olan güven faktöründe yer alan dokuz maddenin faktör yükleri .36 - .64, madde-toplam puan korelasyonları ise $.34-.63$ aralığındadır. Alt ölçeğe ait Cronbach Alpha İç Tutarlık Katsayısise .79'dur. ÖMMÖ'nin son ve dördüncü alt ölçeği olan memnuniyet faktöründe yer alan altı maddenin faktör yükleri .63 - .79, madde-toplam puan korelasyonları ise .57 - .67 aralığındadır. Alt ölçeğe ait Cronbach Alpha İç Tutarlık Katsayısı ise .82'dir. 
Tablo 3. ÖMMÖ'deki Faktör Yükleri, Faktörün Açıkladı̆̆ı Varyans Yüzdeleri, Maddelerin MaddeToplam Puan Korelasyonu, Ortak Varyans, Aritmetik Ortalama, Standart Sapma ve Güvenilirlik Katsayı Değerleri.

\begin{tabular}{|c|c|c|c|c|c|c|c|c|}
\hline Madde No & F1 & F2 & F3 & F4 & $\begin{array}{l}\text { Madde-Toplam } \\
\text { Puan } \\
\text { Korelasyonu* }\end{array}$ & $\begin{array}{c}\text { Ortak Faktör } \\
\text { Varyansı }\end{array}$ & $\overline{\mathrm{X}}$ & Ss \\
\hline 2 & .54 & & & & .48 & .29 & 3.97 & 1.14 \\
\hline 8 & .69 & & & & .58 & 4.47 & 3.59 & 1.25 \\
\hline 11 & .60 & & & & .55 & .35 & 4.06 & 1.15 \\
\hline 14 & .74 & & & & .67 & .55 & 4.02 & 1.17 \\
\hline 16 & .74 & & & & .70 & .54 & 3.95 & 1.13 \\
\hline 19 & .59 & & & & .55 & .35 & 4.09 & 1.14 \\
\hline 21 & .62 & & & & .66 & .39 & 4.04 & 1.09 \\
\hline 23 & .57 & & & & .56 & .33 & 3.97 & 1.09 \\
\hline 26 & .59 & & & & .52 & .35 & 3.84 & 1.35 \\
\hline 27 & .61 & & & & .56 & .38 & 4.17 & 1.04 \\
\hline 6 & & .63 & & & .56 & .40 & 4.19 & .96 \\
\hline 9 & & .47 & & & .45 & .22 & 3.80 & 1.33 \\
\hline 10 & & .57 & & & .45 & .33 & 4.62 & .80 \\
\hline 15 & & .61 & & & .63 & .37 & 3.75 & 1.15 \\
\hline 17 & & .65 & & & .58 & .42 & 3.96 & 1.15 \\
\hline 22 & & .70 & & & .62 & .49 & 4.36 & .91 \\
\hline 28 & & .48 & & & .44 & .23 & 3.86 & 1.18 \\
\hline 30 & & .71 & & & .62 & .51 & 3.85 & 1.09 \\
\hline 1 & & & .36 & & .33 & .13 & 3.99 & 1.13 \\
\hline 3 & & & .68 & & .59 & .46 & 3.85 & 1.15 \\
\hline 4 & & & .62 & & .56 & .39 & 4.22 & .97 \\
\hline 7 & & & .63 & & .55 & .39 & 4.12 & 1.01 \\
\hline 12 & & & .59 & & .53 & .35 & 4.49 & .91 \\
\hline 18 & & & .62 & & .56 & .40 & 3.90 & 1.09 \\
\hline 24 & & & .65 & & .59 & .41 & 4.40 & .89 \\
\hline 31 & & & .66 & & .63 & .43 & 3.85 & 1.09 \\
\hline 32 & & & .69 & & .64 & .45 & 4.13 & 1.03 \\
\hline 5 & & & & .67 & .59 & .46 & 4.36 & .94 \\
\hline 13 & & & & .75 & .65 & .56 & 4.13 & 1.06 \\
\hline 20 & & & & .78 & .64 & .61 & 4.23 & .99 \\
\hline 25 & & & & .63 & .57 & .40 & 4.13 & 1.05 \\
\hline 29 & & & & .72 & .59 & .51 & 4.43 & .91 \\
\hline 33 & & & & .79 & .67 & .63 & 4.23 & 1.02 \\
\hline Öz değeri & 6.29 & 4.82 & 5.50 & 4.34 & & Toplam & & \\
\hline Varyans \% & 16.22 & 8.43 & 15.29 & 7.56 & & 47.50 & & \\
\hline Cronbach Alpha & .83 & .74 & .79 & .82 & & .93 & & \\
\hline
\end{tabular}

* $p<.01 ; \quad$ F1: Dikkat $\quad$ F2: Uygunluk F3: Güven $\quad$ F4: Memnuniyet

ÖMMÖ’ye ait dört alt ölçek, toplam varyansın \% 47.50'sini açılklamaktadır. Buna ek olarak, ölçeğin tamamına ilişkin Cronbach Alpha İç Tutarlık Katsayısı .93'tür. Açıklayıcı faktör analizinde faktör toplam puanları arasındaki ve faktör toplam puanları ile toplam puan arasındaki ilişkinin de incelenmesi gerekmektedir. Yapılan analiz sonucunda faktör toplam puanları arasında anlamlı ve düşük bir ilişkinin çıkması; faktör toplam puanları ile toplam puan arasında ise anlamlı ve yüksek bir ilişki çıkması beklenmektedir. İki faktör arasında yüksek bir ilişkinin çıkması, bu faktörlerin aynı olguyu ölçtüğü şeklinde yorumlanmaktadır. Bu tür durumlarda, aynı olguyu ölçen faktörlerin birleştirilmesi önerilmektedir. Bu koşulun incelenmesi amacıyla gerekli analizler yapılarak dört faktöre ait korelasyon matrisi oluşturulmuştur. Oluşturulan bu korelasyon matrisi Tablo 4'de gösterilmiştir. 
Tablo 4.ÖMMÖ Toplam Puan ve Alt Ölçeklerine İlişsin Korelasyon Matrisi, Aritmetik Ortalamaları ve Standart Sapma Değerleri.

\begin{tabular}{lcccccc}
\hline Faktörler & 1 & 2 & 3 & 4 & $\bar{X}$ & Ss \\
\hline 1. Dikkat & - & & & & 39.70 & 7.28 \\
2. Uygunluk & $.78^{*}$ & - & & & 33.01 & 5.02 \\
3. Güven & $.75^{*}$ & $.76^{*}$ & - & & 36.95 & 5.66 \\
4. Memnuniyet & $.70^{*}$ & $.70^{*}$ & $.73^{*}$ & - & 25.50 & 4.33 \\
\hline Toplam Puan & $.92^{*}$ & $.90^{*}$ & $.90^{*}$ & $.85^{*}$ & 135.16 & 2.04 \\
\hline
\end{tabular}

$* p<.01$

Tablo 4'de de görüldüğü üzere alt ölçeklerin tamamı birbirleri ile anlamlı ve yüksek ilişki içerisindedir. Bu bulgu pek istenmeyen bir sonuçtur; ancak, ölçeğin uyarlama çalışması olması ve alt ölçeklerin toplam puanla oldukça yüksek ve anlamlı bir ilişki içinde olması kabul edilebilir bir durumdur.

Yukarıdaki bulgular ışığında açıklayıcı faktör analizi yapılarak toplamda 33 madde ile güvenilirliği test edilen ÖMMÖ'nin geçerliliğinin test edilmesi amacılyla üçüncü bir uygulama okulunda tekrar uygulanarak, elde edilen veriler ile doğrulayıcı faktör analizi yapılmıștır.

Ölçeğin kullanılabilirliğine emin olmak amacıyla doğrulayıcı faktör analizi için kullanılan 215 veri setinden öncelikle alt $\% 27(n=80)$ ve üst $\% 27^{\prime} l i k(n=80)$ gruplar oluşturulmuş ve maddelerin bu iki grubu birbirinden ayırt edip edemediği incelenmiştir. Bu inceleme sonucunda tüm maddelerin ve toplam puanların grupları anlamlı $(p<.05)$ bir şekilde ayırt edebildiği anlaşılmıştır. Analize dahil edilen 33 maddenin aritmetik ortalamalarının 2.93 - 3.94 aralığında, standart sapmalarının 1.38 1.55 aralığında olduğu belirlenmiştir. Bu bulgulardan sonra doğrulayıcı faktör analizi basamaklarına geçilmiştir.

Doğrulayıcı faktör analizinde öncelikli olarak önerilen modelin standardize edilmiş değerleri ve her maddenin anlamlılığının incelenmesi gerekmektedir. Bu koşul için ölçekteki maddelerin standardize edilmiş değerleri incelenmiş, Şekil 2'de bu değerler ve bu değerlere ait diyagram gösterilmiştir. 


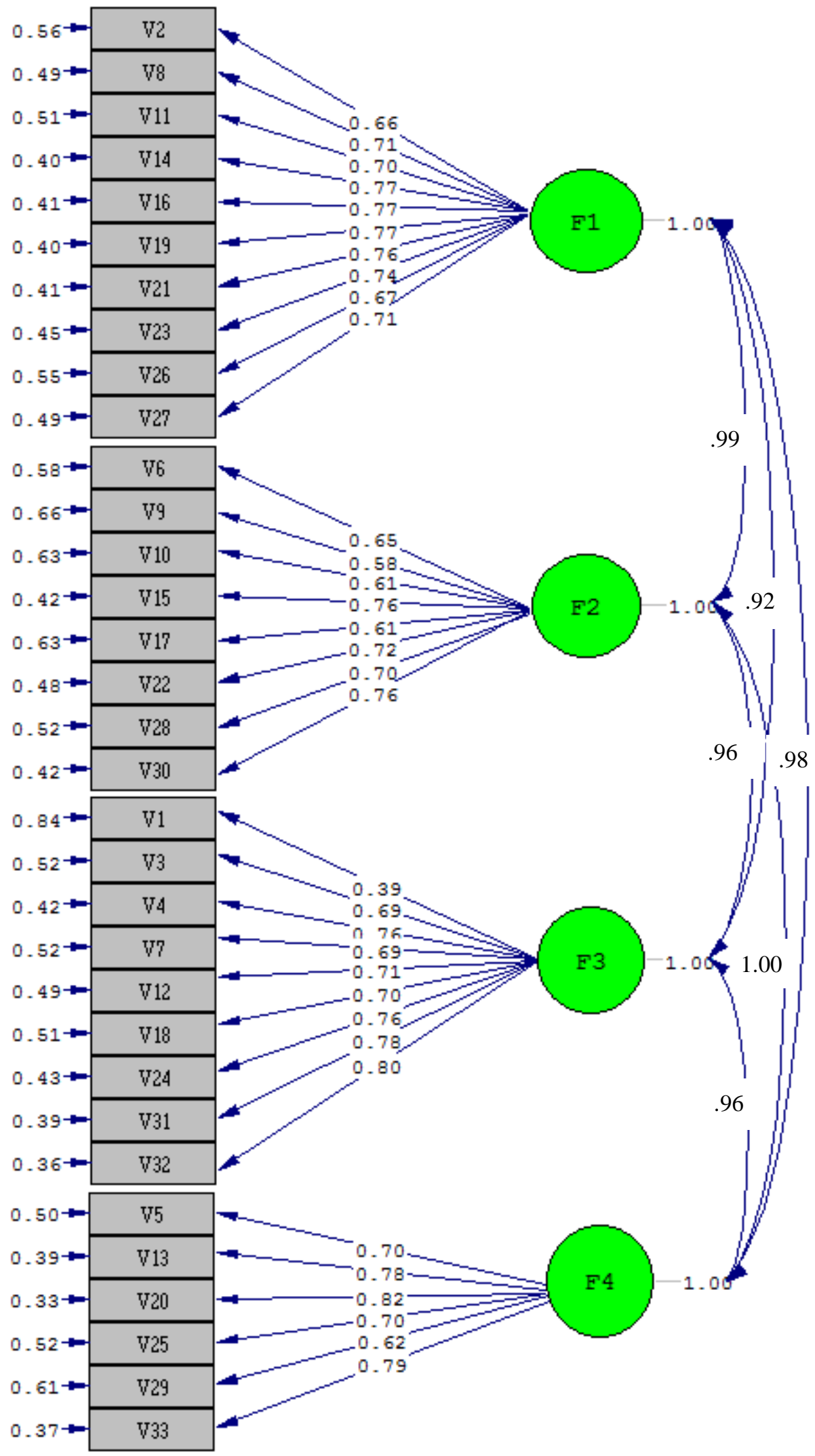

Chi-Square=1133.01, df=489, P-value=0.00000, RMSEA $=0.067$

Şekil 2.Doğrulayıcı faktör analizi sonucunda elde edilen ÖMMÖ maddelerinin standardize edilmiş değerleri. 
Doğrulayıcı faktör analizinde her bir maddeye ait standardize edilmiş değerin 1.00 ve üstü bir değerde olmaması gerekmektedir. Bu model için standardize edilmiş değerlerin .33 - .84 aralığında olduğu ve 1.00 değerini aşmadığı tespit edilmiş, gözlenen değişkenler arasındaki korelasyonun uygun düzeyde olduğu sonucuna ulaşılmıştır. Bu aşamadan sonra maddelerin $t$ değerlerinin incelenmesi ve .05 düzeyinde anlamlı farklılığa sahip olduğunun belirlenmesi gerekmektedir. Bu koşul incelenmiş ve Şekil 3'de maddelere ait $t$-değerleri ve bu değerlere ait diyagram gösterilmiştir. Son olarak indekslere ait sınır ve kabul değerleri, genel kabul gören sınır değerleri ve ÖMMÖ'ne ait değerler belirlenerek Tablo 5'de gösterilmiştir.

Tablo 5.Uyum İndeksleri Sinır Değerleri ve ÖMMÖ Doğrulayıcı Faktör Analizi Uyum Değerleri.(Schermelleh-Engel, MoosbruggerveMüller, 2003).

\begin{tabular}{llrr}
\hline Uyum İndeksi & Uyum Değeri & $\begin{array}{r}\text { Kabul Edilebilir Uyum } \\
\text { Değeri }\end{array}$ & $\begin{array}{r}\text { ÖMMÖ’ne Ait Uyum } \\
\text { Değerleri }\end{array}$ \\
\hline$\chi^{2} /$ df & $\chi^{2} / d f<2$ & $\chi^{2} / d f<5$ & 2.32 \\
RMSEA & RMSEA $<.05$ & RMSEA $<.08$ & .07 \\
SRMR & SRMR $<.05$ & SRMR $<.08$ & .04 \\
RMR & RMR $<.05$ & RMR $<.08$ & $.09^{*}$ \\
GFI & GFI $>.95$ & GFI $>.90$ & $.81^{*}$ \\
AGFI & AGFI $>.90$ & AGFI $>.85$ & $.78^{*}$ \\
CFI & CFI $>.95$ & CFI $>.90$ & .98 \\
NFI & NFI $>.95$ & NFI $>.90$ & .97 \\
\hline
\end{tabular}

* Kabul edilebilir değerler dışında kalan uyum değerleri.

Tablo 5 incelendiğinde ÖMMÖ doğrulayıcı faktör analizine ait değerlerin genel olarak kabul edilebilir sınırlar içinde olduğu, sadece ortalama hataların karekökünün (RMR), iyilik uyum indeksinin (GFI) ve düzeltilmiş iyilik uyum indeksinin (AGFI) bu sınırlar içinde olmadığı tespit edilmiştir. Ancak, bu değerlerinde kabul edilebilir sınır değerlerine oldukça yakın bir değerde olması ve $\chi^{2} / d f$ değerinin 2.32 olarak hesaplanması nedeniyle bu ölçeğin iyi bir uyuma sahip olduğu sonucuna ulașilmıștır.

Son olarak doğrulayıcı faktör analizine dahil edilen verilerin Cronbach Alpha İç Tutarlık Katsayısı incelenmiş, bu değerin dikkat alt ölçeği için .92, uygunluk alt ölçeği .88, güven alt ölçeği için .90 , memnuniyet alt ölçeği için .88 ve toplam ÖMMÖ için .97 olduğu sonucuna ulaşılmıștır. 


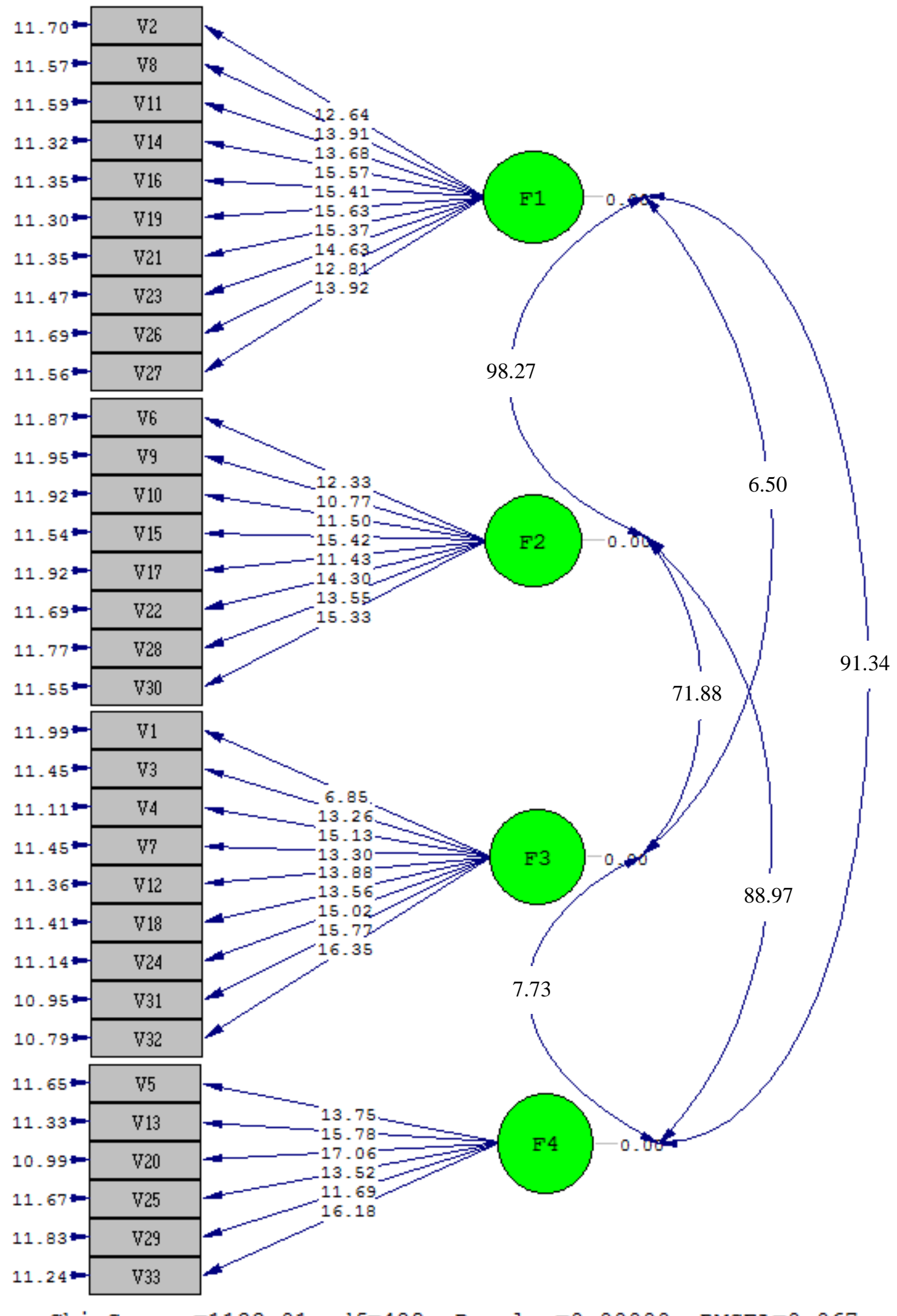

Chi-Square=1133.01, $d f=489, \mathrm{P}-\mathrm{value}=0.00000, \mathrm{RMSEA}=0.067$

Şekil 3.Doğrulayıcı faktör analizi sonucunda elde edilen ÖMMÖ maddelerinint-değerleri.

Yukarıdaki veriler ışığında ÖMMÖ'ye ait bu sürümünün ortaokul öğrencilerine geçerli ve güvenilir șekilde uygulanabileceğine karar verilmiștir. Ölçeğin orijinal sürümünde alınan puanların en düşük noktası 36.00, orta noktası 108.00, en yüksek noktası 180.00 olarak belirtilmesine rağmen, bu sürümde alınabilecek puanların en düşük noktası 33.00, orta noktası 99.00 ve en yüksek noktası 
165.00 olarak belirlenmiştir. Bu bilgiler ıșığında ölçek puanlaması normal dağılım ilkelerine göre hesaplanmış ve Tablo 6'da gösterilmiştir. ÖMMÖ'nin ve alt ölçeklerinin puan yorumlarının, belirtilen bu alt-üst sınırlar içinde yapılması önerilmiştir:

Tablo 6.ÖMMÖ ve Alt Ölçek Seviyelerine İlişsin Alt-Üst Puan Değerleri.

\begin{tabular}{lccccc}
\cline { 1 - 5 } \multicolumn{1}{c}{ Seviye } & \multirow{2}{*}{ Çok Düsçük } & Düşük & Orta & Yüksek & Çok Yüksek \\
\hline Dikkat & $10.00-11.50$ & $11.51-16.50$ & $16.51-43.49$ & $43.50-48.49$ & $48.50-50.00$ \\
Uygunluk & $8.00-9.25$ & $9.26-13.25$ & $13.26-34.74$ & $34.75-38.74$ & $38.75-40.00$ \\
Güven & $9.00-10.25$ & $10.26-14.75$ & $14.76-39.24$ & $39.25-43.74$ & $43.75-45.00$ \\
Memnuniyet & $6.00-6.75$ & $6.76-10.00$ & $10.01-25.99$ & $26.00-29.24$ & $29.25-30.00$ \\
\hline ÖMMÖ & $33.00-37.00$ & $37.01-54.00$ & $54.01-143.99$ & $144.00-160.99$ & $161.00-165.00$ \\
\hline
\end{tabular}

\section{TARTIŞMA, SONUÇ VE ÖNERILER}

Materyaller öğretimin başarıya ulaşmasını sağlayan önemli faktörlerden birisidir. Bu materyallerin değerlendirilmesi için birçok ölçme aracı ilgili alanyazında bulunmasına rağmen bir model çerçevesinde hazırlanan ölçme aracına nadiren rastlanılmaktadır. Buna ek olarak genellikle yükseköğretim ya da yetişkin eğitimi için hazırlanan bu ölçme araçlarının nadir olarak ilk-ortaokul düzeyindeki uygulamaları görülmektedir. Öğretimde akademik başarıya genel olarak odaklanılmasına rağmen akademik başarıyı doğrudan ya da dolaylı yoldan etkileyen değişkenlere gerektiği kadar odaklanılmamaktadır. Bu değișkenlerin bașında da motivasyon gelmekte ve motivasyonun öğretimde sürekli ölçülmesinin yararlı olacağı düșünülmektedir. Motivasyonu sağlayacak birçok etken olmasına rağmen bunların bașında öğretim materyaline karşı oluşan motivasyon gelmekte ve bunun ölçülmesi gerekmektedir. Uyarlanan ölçme aracının bu ölçümün yapılmasına olanak sağlayacağından, oldukça yararlı olacağı düşünülmektedir. Bu düşünceden hareketle hazırlanan ölçme aracının geçerliği için ölçeğin kapsam ve yapı geçerliliği incelenmiş, güvenilirlik için ise iç tutarlılık katsayılarına bakılmıştır. Ölçeğin yapı geçerliliği ise doğrulayıcı faktör analizi ile incelenmiştir.

Ölçeğin güvenilirliği için iç tutarlılık katsayılarına bakılmış, CronbachAlphaİç Tutarlılık Katsayısı açıklayıcı faktör analizi sonucunda .93, doğrulayıcı faktör analizi sonucunda .97 olarak hesaplanmıştır. Elde edilen farklı ancak birbirine oldukça yakın bu iki iç tutarlılık katsayılarının, orijinal ölçeğin geliştirilmesi çalışmasında ve ölçekten yararlanılan diğer çalışmalarda elde edilen iç tutarlılık katsayıları ile uyumlu olduğu sonucuna ulaşılmıștır. Buna ek olarak 33 maddelik dört faktörlü ölçme aracının toplam varyansı \% 47.50'sini açıkladığı hesaplanmıștır. Bazı araștırmacılar (Sheskin, 2004) açıklanan toplam varyansın en az \% 70.00 olması gerektiğini belirtirken, bazı araştırmacılar (Tavşancıl, 2002) toplam varyansın en az \% 40.00 olması gerektiğini, bazı araştırmacılar ise (Büyüköztürk, 2005) toplam varyansın \% 30.00 ve üstü bir değerde olmasının kabul edilebileceğini belirtmiștir. Güvenilirlik katsayısının yüksek çıkması ve bu ifadelerden yola çıkılarak ölçme aracı açıklayıcı faktör analiz sonuçlarının uygun değerlerde olduğu kabul edilmiştir.

Ölçek yapısının uyum indeksleri incelendiğinde $\chi^{2} / \mathrm{sd}=2.32$, SRMR $=.04$, RMSEA $=.07$, $\mathrm{AGFI}=.78, \mathrm{GFI}=.81, \mathrm{NFI}=.97$, ve $\mathrm{CFI}=.98$ uyum indekslerine sahip olduğu ortaya çıkmıştır. Byrne'ye (1998) göre bu uyum indeksleri kabul edilebilir uyumu göstermektedir. Bu değerlerden ölçek yapısının kabul edilebilir uyuma sahip olduğu belirlenmiştir.

Araştırmanın amaçları doğrultusunda olmamasına rağmen ortaokul öğrencilerinin ters maddeleri algılayamadıkları/doğru kodlayamadıkları anlaşılmıştır. Bu nedenle bu yaş grubundaki katılımcılara uygulanacak ölçme araçlarında bu ters maddelerin kullanılmaması önerilmektedir. Bu öneriye ek olarak ölçme aracının daha geniş örneklem gruplarında tekrar uygulanarak doğrulayıcı faktör analizine tekrar bakılması önerilmekte ve bu çalışmanın sonuçları da derlenerek ulusal alanda yapılan ÖMMÖ’nün genel değerlendirilmesinin yapılması önerilmektedir. 


\section{Teşekkür}

$\mathrm{Bu}$ çalışma Prof. Dr. Ahmet DOĞANAY danışmanlığında yürütülen doktora tezinden üretilmiştir. Bu kapsamda Çukurova Üniversitesi Bilimsel Araştırma Projeler Birimi tarafından SDK2014-3098nolu proje kapsamında desteklenmektedir.

\section{KAYNAKÇA}

Acar, S. (2009). Web destekli performans tabanlı öğrenmede motivasyon stratejilerinin öğrencilerin akademik başarılarına, kalıcılıklarına ve tutumlarına etkisi. Yayımlanmamış doktora tezi, Gazi Üniversitesi, Ankara.

Ahmed, W. \& Bruinsma, M. (2006). A structural model of self-concept, autonomous motivation and academic performance in cross-cultural perspective. Electronic Journal of Research in EducationalPsychology, 4(3), 551-576.

Aladağ, Ö. (2007). Örgüt kültürü ile motivasyon arasındaki ilişkinin araştırılması (Eskişehir Sarar A.Ş. örneği). Yayımlanmamış yüksek lisans tezi, Dumlupınar Üniversitesi, Kütahya.

Aydın, S., Yerdelen, S., Gürbüzoğlu-Yalmancı, S., ve Göksu, V. (2014). Biyoloji Öğrenmeye Yönelik Akademik Motivasyon Ölçeği: Ölçek geliştirme çalışması. Eğitim ve Bilim, 39(176), 425-435.

Balaban-Salı, J. (2002). Uzaktan öğretimde güdüleyici öğrenme sistemlerinin tasarımı. Uluslararası Açık ve Uzaktan Eğitim Sempozyumu, Eskişehir.

Brophy, J. (1998). Motivating students to learn. Modison, WI: McgrawHill.

Büyüköztürk, Ș. (2005). Sosyal bilimler için veri analizi el kitabı (2. Baskı.). Ankara: PegemA Yayıncllık.

Byrne, B. M. (1998). Structural equation modeling with LISREL, PRELIS and SIMPLIS: Basic concepts, applications, and programming's. London: Lawrence Erlbaum Associates, Publishers.

Carey, L. M., Carey, J. O. \& Pearson, L. C. (1991). Using measures of academic motivation for formative evaluation of the instructional strategy. In the Annual Meeting of the American Educational Research Association, Chicago, MI.

Çetin, Ü., ve Mahiroğlu, A. (2008). ARCS motivasyon modeli uyarınca tasarlanmış eğitim yazılımının öğrencilerin akademik başarısına ve öğrenmenin kalıcılığına etkisi. Ahi Evran Üniversitesi Kırșehir Eğitim Fakültesi Dergisi, 9(3), 101-112.

Chan, K. W., Wong, K. Y. A., \& Lo, S. C. E. (2012). Relational analysis of intrinsic motivation, achievement goals, learning strategies and academic achievement for Hong Kong secondary students. The Asia-Pacific Education Researcher, 21(2), 230-243.

Cobb, C. (2013). The use of an animated pedagogical agent as a mnemonic device to promote learning and motivation in online education. Yayımlanmamış doktora tezi, Walden University, Texas.

Dalgety, J., Coll, R. K., \& Jones, A. (2003). Development of chemistry attitudes and experiences questionnaire (CAEQ). Journal of Research in Science Teaching, 40(7), 649-668.

De Vellis, R. F. (2003). Scale development: Theory and applications (2nd ed.). Thous and Oaks: Sage Publications.

Deci, E. L. (1972). The effects of contingent and noncontingent reward sand controls on intrinsic motivation. Organizational Behavior and Human Performance, 8(2), 217-229.

Deci, E. L., \& Ryan, R. M. (1985). Intrinsic motivation and self-determination in human behavior. New York: Springer Science \& Business Media.

Deci, E. L., \& Ryan, R. M. (2000). The "what" and "why" of goal pursuits: Human needs and the selfdetermination of behavior. Psychological Inquiry, 11(4), 227-268.

Dede, Y. (2003). ARCS Motivasyon Modeli'nin öğrencilerin matematiğe yönelik motivasyonlarına etkisi. Pamukkale Üniversitesi Eğitim Fakültesi Dergisi, 2(14), 173-182.

Dede, Y. ve Yaman, S. (2008). Fen öğrenmeye yönelik motivasyon ölçeği: Geçerlik ve güvenirlik çalışması. Necatibey Eğitim Fakültesi Elektronik Fen ve Matematik Eğitimi Dergisi, 2(1), 19-37.

Doğanay, A. ve Sarı, M. (2012). Düşünme Dostu Sınıf Ölçeği (DDSÖ) geliştirme çalışması. İlköğretim Online, 11(1), 214-229.

Eccles, J. S., Wigfield, A., \& Schiefele, U. (1998). Motivation to succeed. In N. Eisenberg (Ed.), Handbook of child psychology: Social, emotional, and personality development (5th ed., pp. 1017-1095). New York: Wiley.

Ersarı, G., ve Naktiyok, A. (2012). İş görenin içsel ve dışsal motivasyonunda stresle mücadele tekniklerinin rolü. Atatürk Üniversitesi Sosyal Bilimler Enstitüsü Dergisi, 16(1), 81-101.

Eryılmaz, A., ve Ercan, L. (2014). Ergenler için Ders Çalışmaya Motive Olma Ölçeğinin geliştirilmesi. Başkent University Journal of Education, 1(1), 34-40.

Eryllmaz, H. (2013). Electronic and interactive book applications for distance education system. An example from Turkey: Anadolu University. In ICERI2013 Proceedings (pp. 7237-7239), Seville.

Fortier, M. S., Vallerand, R. J., \& Guay, F. (1995). Academic motivation and school performance: Toward a structural model. Contemporary Educational Psychology, 20(3), 257-274. 
Gabrielle, D. M. (2003). The effects of technology-mediated instructional strategies on motivation, performance and self-directed learning. Yayımlanmamış doktora tezi, Florida State University, Florida.

Gillet, N., Vallerand, R. J., \& Lafrenière, M. A. K. (2012). Intrinsic and extrinsic school motivation as a function of age: The mediating role of autonomy support. Social Psychology of Education, 15(1), 77-95.

Glynn, S. M., Taasoobshirazi, G., \&Brickman, P. (2007). Nonscience majors learning science: A theoretical model of motivation. Journal of Research in Science Teaching, 44(8), 1088-1107.

Harter, S. (1981). A new self-report scale of intrinsic versus extrinsic orientation in the classroom: Motivational and informational components Developmental Psychology, 17(3), 300-312.

Huang, D. W., Diefes-Dux, H., Imbrie, P. K., Daku, B., \& Kallimani, J. G. (2004). Learning motivation evaluation for a computer-based instructional tutorial using ARCS Model of Motivational Design. In Frontiers in Education, 2004. FIE 2004. 34th. IEEE.

Huett, J. B. (2006). The effects of ARCS-based confidence strategies on learner confidence and performance in distance education. Yayımlanmamıs doktora tezi, University of North Texas, Texas.

Kalaycı, Ș. (2009). SPSS uygulamalı çok değişkenli istatistik teknikleri (4. Baskı). Ankara: Asil Yayıncılık.

Kaplan, M. (2007). Motivasyon teorileri kapsamında uygulanan özendirme araçlarının iş gören performansına etkisi ve bir uygulama. Yayımlanmamış yüksek lisans tezi, Ankara: Atılım Üniversitesi.

Keller, J. M. (1983). Motivational design of instruction. In C. M. Reigeluth (Ed.) Instructional design theories and models: An overview of their current status (pp. 383-434). Hillsdale: Lawrence Erlbaum.

Keller, J. M. (1987). Development and use of the ARCS model of instructional design. Journal of Instructional Development, 10(3), 2-10.

Keller, J. M. (1999). Motivation in cyber learning environments. Educational Technology International, 1(1), 730.

Keller, J. M. (2006). Development of two measures of learner motivation: CIS and IMMS.[Online]: Retrieved on March 20, 2014, from http://olpcorps.wikispaces.com/file/view/ARCSMEA+Partial+Draft+060222. doc

Keller, J. M. (2008). First principles of motivation to learn and e3-learning. Distance Education, 29(2), 175-185.

Keller, J.M. (2010). Motivational design for learning and performance: The ARCS Model approach. New York, NY: Springer.

Keller, J. M., \& Kopp, T. (1987). An application of the ARCS Model of Motivational Design. In C. M. Reigeluth (Ed.), Instructional-design theories in action: Lessons illustrating selected theories and models (pp. 289-320). Hillsdale: Lawrence Erlbaum.

Keller, J. M., \& Suzuki, K. (1988). Use of the ARCS motivation model in courseware design. In D. H. Jonassen (Ed.), Instructional designs for microcomputer courseware(pp. 289-320). Hillsdale: Erlbaum.

Kutlu, H. ve Sözbilir, M. (2011). Yaşam temelli ARCS öğretim modeliyle 9. sınıf kimya dersi "Hayatımızda Kimya” ünitesinin öğretimi. Ondokuz Mayıs Üniversitesi Eğitim Fakültesi Dergisi, 30(1), 29-62.

Lau, S. H., \& Woods, P. C. (2009). Understanding the behavior changes in belief and attitude among experienced and inexperienced learning object users. Computers \& Education, 52(2), 333-342.

Lepper, M. R. (1988). Motivational considerations in the study of instruction. Cognition and Instruction, 5(4), 289-309.

Lussier, R. N. (1990). Human relations in organizations: A skill-building approach. Homewood, IL: Irwin.

Main, R. G. (1993). Integrating motivation into the instructional design process. Educational Technology, 33(12), 37-41.

Malone, T. \& Lepper, M. (1987). Making learning fun: A taxonomy of intrinsic motivations for learning. In R. Snow \& M. Farr (Eds.), Aptitude, learning, and instruction: Cognitive and affective process analyses (pp. 223-253). Hillsdale, NJ: Erlbaum

Marovitz, M., \& Buckley, J. (1987). Integrating ARCS Motivational Theory into the Component Display Theory of Instructional Design. In ERIC, [Online]: Retrieved on February 10, 2014, from http://eric.ed.gov/?id=ED292872

Maslow, A. H. (1943). A theory of human motivation. Psychological Review, 50(4), 370-396.

Means, T. B., Jonassen, D. H., \& Dwyer, F. M. (1997). Enhancing relevance: Embedded ARCS strategies vs. purpose. Educational Technology Research and Development, 45(1), 5-17.

Mottaz, C. J. (1985). The relative importance of intrinsic and extrinsic rewards as determinants of work satisfaction. The Sociological Quarterly, 26(3), 365-385.

Newstrom, J. W., \& Davis, K. (2002). Organizational Behavior human behavior at work. New York: McGraw-Hill.

Niemiec, C. P., \& Ryan, R. M. (2009). Autonomy, competence, and relatedness in the classroom applying selfdetermination theory to educational practice. Theory and Research in Education, 7(2), 133-144.

Pajares, F. (1996). Self-efficacy beliefs in academic settings. Review of Educational Research, 66(4), 543-578.

Pintrich, P. R., \& Maehr, M. L. (Eds.). (2004). Advances in motivation and achievement: Motivating students, improving schools (Vol. 13). Oxford: JAI, An Imprint of Elsevier Science. 
Reeve, J.M. (2004). Understanding motivation and emotion. USA: John Willey \& Sons.

Ryan, R. M., \& Deci, E. L. (2000). Self-determination theory and the facilitation of intrinsic motivation, social development, andwell-being.AmericanPsychologist,55(1), 68-78.

Schermelleh-Engel, K., Moosbrugger, H., \& Müller, H. (2003).Evaluating the fit of structural equation models: Tests of significance and descriptive goodness-of-fit measures. Methods of Psychological Research Online, $8(2), 23-74$.

Schunk, D. H., \& Pajares, F. (2001).The development of academic self-efficacy. In A. Wigfield \& J. Eccles (Eds). Development of achievement motivation (pp. 15-31). San Diego: American Pres.

Sheskin, D. J. (2004). Handbook of parametric and nonparametric statistical procedures (3rd ed.). Boca Raton: Chapman \& Hall/CRC

Slavin, R. E. (2003). Educational psychology: Theory into practice (7th ed.). Boston: Allyn\& Bacon.

Small, R. V. (1997). Assessing the motivational quality of world wide websites. ERIC Clearinghouse on Information and Technology. (ED number pending, IR 018 331)

Song, S. H. (1998). The effects of motivationally adaptive computer assisted instruction developed through the ARCS Model. Yayımlanmamıș doktora tezi, Florida State University, Florida.

Song, S. H., \& Keller, J. M. (1999). The ARCS Model for developing motivationally-adaptive computer-assisted instruction. In ERIC, [Online]: Retrieve don February 10, 2014, from http://files.eric.ed.gov/fulltext/ED436181.pdf

Steers, R. M., \& Porter, L. W. (1991). Motivation and work behavior (5th ed.). New York, NY: McGraw-Hill.

Tavşancıl, E. (2002). Tutumların ölçülmesi ve SPSS ile veri analizi. Ankara: Nobel Yayın Dağıtım.

TDK (2015).T.C. Başbakanlık Atatürk Kültür, Dil ve Tarih Yüksek Kurumu Türk Dil Kurumu, http://www.tdk.gov.tr/index.php?option=com gts\&arama=gts\&guid=TDK.GTS.55c34230d02816.616 $\underline{5015}$ adresinden 20 Şubat 2015 tarihinde erişilmiștir.

Tuan, H. L., Chin, C. C., \& Shieh, S. H. (2005). The development of a questionnaire to measure students' motivation towards science learning. International Journal of ScienceEducation,27(6), 639-654.

Watters, J. J., \& Ginns, I. S. (2000). Developing motivation to teach elementary science: Effect of collaborative and authentic learning practices in preservice education. Journal of Science Teacher Education, 11(4), 301-321.

Wolters, C. A., \& Rosenthal, H. (2000). The relation between students' motivational beliefs and their use of motivational regulation strategies. International Journal of Educational Research, 33(7), 801-820.

Woodworth, R. S. (1918). Dynamic psychology. New York: Columbia University Press.

Zusho, A., Pintrich, P. R., \& Coppola, B. (2003). Skill and will: The role of motivation and cognition in the learning of college chemistry. International Journal of Science Education, 25(9), 1081-1094. 
EK: Öğretim Materyaline İlişkin Motivasyon Ölçeği Maddeleri.

\begin{tabular}{ll|lll} 
5. Çok Doğru & 4. Doğru & 3. Orta Derecede Doğru & 2. Biraz Doğru & 1. Doğru değil
\end{tabular}

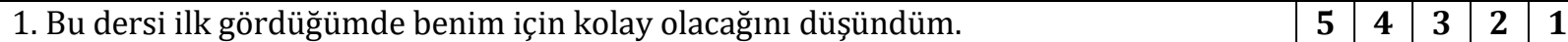

\begin{tabular}{|l|l|l|l|l|l|}
\hline 2. Bu dersin başında ilgimi çeken ilginç şeyler vardı. & $\mathbf{5}$ & $\mathbf{4}$ & $\mathbf{3}$ & $\mathbf{2}$ & $\mathbf{1}$ \\
\hline
\end{tabular}

3. Bu ders materyalini/aracını (bilgisayar, kitap gibi) tahmin ettiğimden daha kolay anladım.

4. Giriş bilgilerini okuduktan/dinledikten sonra, bu dersten neler öğrenmem gerektiğinden emin oldum.

5. Bu dersin alıştırmalarını yapmak, bana başarı duygusu kazandırdı.

\begin{tabular}{l|l|l|l|l|}
5 & 4 & 3 & 2 & 1
\end{tabular}

6. Bu dersin içeriğinin önceden öğrendiklerimle nasıl ilişkisi olduğu benim için açık ve netti.

7. Ders materyalinde/aracında olması gerektiği kadar bilgi vardı. Önemli olan şeyleri ayırabildim.

8. Bu dersteki kullanılan materyal/ders aracı dikkat çekiciydi.

9. Bu ders materyalinin/aracının, bazı insanlar için nasıl önemli olabileceğini gösteren resim, hikaye ya da örnekler vardı.

10. Bu dersi bașarıyla tamamlamak benim için önemliydi.

11. Yazıların/seslerin kalitesi, derse dikkatimi vermemi kolaylaştırdı.

12. Bu derse çalıștıkça konuları öğreneceğimden emin oldum.

13. Bu dersten o kadar keyif aldım ki bu konuyla ilgili daha çok şey öğrenmek istedim.

14. Bu materyalde/ders aracında ders anlatımları zevkliydi.

15. Bu materyalin/ders aracının içeriği ilgimi çeken konulara göre hazırlanmıștı.

16. Bilgilerin ders materyalinde düzenleniş biçimi, dikkatimi vermemi kolaylaştırdı.

17. Ders materyalinde, bu dersteki bilgileri insanların nasıl kullandığına dair örnekler ve açıklamalar vardı.

18. Bu dersteki alıștırmalar çok kolaydı.

19. Bu derste merak uyandıran şeyler vardı.

20. Bu dersi çalışmaktan gerçekten zevk aldım.

21. Bu derste konu tekrarların sayısı yeterliydi. Hiç sıkılmadım.

22. Bu dersteki bilgiler ve bilgilerin veriliş şekli, bu dersin önemli olduğunu düşünmemi sağladı.

23. Bu derste tahmin etmediğim ya da şaşırtıcı ve yararlı bilgiler öğrendim.

24. Bu dersi bir süre çalıştıktan sonra, bu dersten bașarılı olacağıma emin oldum.

25. Alıştırmalardan sonraki dönütler (geri bildirimler/yorumlar) çalışmamın

karşılığını aldığımı hissetmemi sağladı.

26. Okuma parçaları, alıştırmalar, resimler, videolar, sesler gibi çeșitli öğeler derse

dikkatimi vermeme yardımcı oldu.

27. Ders materyalindeki yazıların șekli benim için uygundu.

28. Bu dersin içeriğini, kendi hayatımdaki şeylerle ilişkilendirebildim.

29. Bu dersi bașarıyla tamamlamak kendimi iyi hissettirdi.

30. Bu ders içeriğinin, benim için faydalı olacağına inandım.

31. Bu ders materyalinin tüm bölümlerini anladım.

32. Ders materyali içeriği iyi hazırlanmıştı. Bu nedenle derste başarılı olacağıma dair güvenim arttı.

33. Ders o kadar güzel hazırlanmıștı ki bu dersi işlemek benim için bir zevkti.

\begin{tabular}{lllllll}
5 & 4 & 3 & 2 & 1 \\
\hline
\end{tabular}

\begin{tabular}{l|l|l|l|l}
5 & 4 & 3 & 2 & 1 \\
\hline
\end{tabular}

\begin{tabular}{|l|l|l|l|l|}
5 & 4 & 3 & 2 & 1
\end{tabular}

\begin{tabular}{l|lll|l|l}
5 & 4 & 3 & 2 & 1 \\
\hline
\end{tabular}

\begin{tabular}{l|l|l|l|l|}
5 & 4 & 3 & 2 & 1 \\
\hline
\end{tabular}

$\begin{array}{lllllll}5 & 4 & 3 & 2 & 1\end{array}$

\begin{tabular}{lllllll}
5 & 4 & 3 & 2 & 1 \\
\hline
\end{tabular}

\begin{tabular}{|l|l|l|l|l|}
$\mathbf{5}$ & $\mathbf{4}$ & $\mathbf{3}$ & $\mathbf{2}$ & $\mathbf{1}$ \\
\hline
\end{tabular}

\begin{tabular}{llllll}
5 & 4 & 3 & 2 & 1 \\
\hline
\end{tabular}

\begin{tabular}{|l|l|l|l|l|}
5 & $\mathbf{4}$ & $\mathbf{3}$ & $\mathbf{2}$ & $\mathbf{1}$ \\
\hline
\end{tabular}

\begin{tabular}{llllll}
5 & 4 & 3 & 2 & 1 \\
\hline
\end{tabular}

\begin{tabular}{|l|l|l|l|l|}
$\mathbf{5}$ & $\mathbf{4}$ & $\mathbf{3}$ & $\mathbf{2}$ & $\mathbf{1}$ \\
\hline
\end{tabular}

\begin{tabular}{llllll}
5 & 4 & 3 & 2 & 1 \\
\hline
\end{tabular}

\begin{tabular}{|l|l|l|l|l}
5 & 4 & 3 & 2 & 1
\end{tabular}

\begin{tabular}{|l|l|l|l|l|}
5 & 4 & 3 & 2 & 1 \\
\hline & 4 & 3 & 2 & 1
\end{tabular}

\begin{tabular}{|l|l|l|l|l|}
5 & 4 & 3 & 2 & 1 \\
\hline
\end{tabular}

\begin{tabular}{lllllll}
5 & $\mathbf{4}$ & $\mathbf{3}$ & $\mathbf{2}$ & $\mathbf{1}$ \\
\hline
\end{tabular}

$\begin{array}{lllllll}5 & \mathbf{4} & \mathbf{3} & \mathbf{2} & \mathbf{1}\end{array}$

\begin{tabular}{l|lllll}
5 & 4 & 3 & 2 & 1
\end{tabular}

\begin{tabular}{l|l|l|l|l|}
5 & 4 & 3 & 2 & 1 \\
\hline & 4 & 3 & 2 & 1 \\
\hline
\end{tabular}

\begin{tabular}{|l|l|l|l|l|}
5 & $\mathbf{4}$ & $\mathbf{3}$ & $\mathbf{2}$ & $\mathbf{1}$ \\
\hline
\end{tabular}

$\begin{array}{lllllll}5 & 4 & 3 & 2 & 1\end{array}$

$\begin{array}{lllllll}5 & 4 & 3 & 2 & 1\end{array}$

\begin{tabular}{l|l|l|l|l|}
5 & 4 & 3 & 2 & 1 \\
\hline & 4 & 3 & 2 & 1 \\
\hline
\end{tabular}

\begin{tabular}{lll|l|l|l|}
5 & 4 & 3 & 2 & 1 \\
\hline 5 & 4 & 3 & 2 & 1
\end{tabular}

\begin{tabular}{|l|l|l|l|l|}
5 & 4 & 3 & 2 & 1 \\
\hline
\end{tabular}

\begin{tabular}{llllll}
5 & 4 & 3 & 2 & 1 \\
\hline
\end{tabular}

\begin{tabular}{l|l|l|l|l}
5 & 4 & 3 & 2 & 1
\end{tabular}

$\begin{array}{lllllll}5 & 4 & 3 & 2 & 1\end{array}$

$\begin{array}{llllll}5 & 4 & 3 & 2 & 1\end{array}$

